\title{
Persepsi dan minat pelatih olahraga sekolah khusus olahraga internasional terhadap sport massage
}

\author{
Galih Priyambada $^{1}$, Andri Tria Raharja ${ }^{1}$, Firmansyah Putra ${ }^{2}$ \\ ${ }^{1}$ Program Studi Pendidikan Olahraga, Fakultas Keguruan Ilmu Pendidikan, Universitas \\ Muhammadiyah Kalimantan Timur. Jalan Ir. H Juanda No. 15, Samarinda, 75124, Indonesia. \\ ${ }^{2}$ Universitas Negeri Yogyakarta. Jalan Colombo No. 1, Karangmalang, Yogyakarta, 55281, Indonesia \\ * Corresponding Author. Email: galih031@umkt.ac.id
}

Received: 2 December 2016; Revised: 27 December 2017; Accepted: 20 April 2018

\begin{abstract}
Abstrak
Penelitian bertujuan untuk mengetahui persepsi dan minat pelatih olahraga Sekolah Khusus Olahraga Internasional Kalimantan Timur terhadap Sport Massage. Metode dalam penelitian ini adalah survei menggunakan instrumen angket. Populasi dalam penelitian ini adalah seluruh pelatih cabang olahraga yang ada di Sekolah Khusus Olahraga Internasional, Kalimantan Timur yang berjumlah 32 orang. Penelitian ini menggunakan teknik sampling jenuh yaitu teknik penentuan sampel bila semua anggota populasi digunakan sebagai sampel yang berjumlah 32 orang. Teknik analisis yang digunakan adalah statistik deskriptif yang dituangkan dalam bentuk persentase. Hasil dalam penelitian ini adalah persepsi pelatih olahraga sekolah khusus olahraga internasional terhadap sport massage termasuk ke dalam kategori baik yaitu sejumlah 12 pelatih olahraga atau sebesar 41,4\%. Minat pelatih olahraga terhadap sport massage termasuk ke dalam kategori baik yaitu sejumlah 12 pelatih olahraga atau sebesar 41,4\%. persepsi dan minat pelatih olahraga terhadap sport massage termasuk ke dalam kategori baik yaitu sejumlah 11 pelatih olahraga atau sebesar 37,9\%.
\end{abstract}

Kata Kunci: persepsi; minat; pelatih olahraga; sekolah khusus olahraga internasional; sport massage

\section{Perception and interests of sports coaches of sekolah khusus olahraga internasional on sport massage}

Abstract
The objective of this study is to find out the perception and interest of the trainers of Sekolah Khusus Olahraga Internasional of East Kalimantan on Sports Massage. The method of this study was a survey using a questionnaire instrument. The population of this study was all coaches of sport in Sekolah Khusus Olahraga Internasional of East Kalimantan, for about 32 people (coaches). This study used a sampling technique, it is the sample determination technique when all member of the population used as the sample. The analysis technique used in this study was descriptive statistics which described in percentage form. The results of this study are the perception of sports coaches of Sekolah Khusus Olahraga Internasional on sports massage which included good category were 12 sports trainers or equal to $37.5 \%$. The interest of sports trainers on sports massage which is included in a good category were 12 trainers or $37.5 \%$.

Keywords: perception, interest, sport trainer, sekolah khusus olahraga internasional, sport massage

How to Cite: Priyambada, G., Raharja, A., \& Putra, F. (2018). Persepsi dan minat pelatih olahraga sekolah khusus olahraga internasional terhadap sport massage. Jurnal Keolahragaan, 6(1), 77-86. doi:http://dx.doi.org/10.21831/jk.v6i1.21180

http://dx.doi.org/10.21831/jk.v6i1.21180

\section{PENDAHULUAN}

Massage merupakan bentuk penanganan yang dilakukan untuk meredakan ketegangan pada otot karena beberapa alasan atau akibat. Massage pada seseorang dilakukan dengan tuju- an memberikan rasa nyaman dan melemaskan otot agar dalam melakukan aktifitas fisik seperti latihan olahraga dan aktifitas fisik lainnya dapat berjalan dengan lancar serta meminimalkan terhadap risiko terjadinya cedera. 
Ilmu massage atau memijat jika diperhatikan pada lingkungan masyarakat merupakan warisan dari nenek moyang. Banyak yang mengatakan seseorang yang memiliki kemampuan memijat merupakan keturunan dari saudaranya yang lebih tua, atau kemampuan yang diturunkan dari nenek moyang. Jika diperhatikan dalam setiap kumpulan masyarakat, baik bersosialisasi dalam suatu kegiatan rakyat atau dalam perkumpulan biasa. Sering dijumpai seseorang melakukan pijat memijat yang tidak disadari hal itu merupakan kemampuan bawaan atau alami yang dimiliki manusia.

Kemampuan memijat yang membudaya pada setiap kehidupan manusia dalam bermasyarakat merupakan bentuk budaya yang dapat membuktikan bahwa manusia merupakan makhluk sosial. Sehingga dalam kehidupan manusia secara umum jika dikaitkan dengan kemampuan alami atau kemampuan memijat maka terdapat korelasi yang mampu menjelaskan bahwa manusia merupakan makhluk yang mampu mengembangkan kemampuan dan berhubungan langsung dengan kehidupan sehari-hari.

Perkembangan massage pada masa dahulu dikatakan sudah mengakar dari nenek moyang. Menjadi metode alami dalam penanganan dari berbagai gejala tubuh, seperti kurang nyaman pada bagian otot, persendian, dan bahkan hingga kondisi tubuh kurang fit karena aktifitas yang melelahkan seringkali diberikan terapi menggunakan massage yang hanya saja metode tersebut berbeda-beda.

Massage atau pijat yang biasa dikenal di lingkungan masyarakat secara umum merupakan metode khusus di luar medis yang sering dilakukan oleh beberapa orang. Hal tersebut biasa dilakukan saat kondisi tertentu pada tubuh hingga saat waktu senggang sebagai media sosialisasi bagi beberapa masyarakat. Kebiasaan pijat memijat yang sudah membudaya saat ini menjadi tren yang semakin ke depan menjadi semakin digemari.

Kegiatan massage saat ini semakin ramai di masyarakat. Banyaknya perkumpulan dan pelatihan yang diadakan oleh unsur masyarakat semakin meningkatkan sumber daya manusia yang cakap dan terampil dalam hal massage. Perkembangan olahraga di Indonesia seiring dengan kemajuan teknologi sehingga semakin mudah mendapatkan informasi terkait sport massage dan olahraga.

Perkembangan olahraga yang dapat memberikan kesempatan pada generasi terampil dalam bidang pelayanan jasa massage yang dalam hal ini sport massage untuk lebih aktif dan turut tergabung dalam setiap event dan acara kejuaraan serta pelatihan. Secara tidak langsung memberikan lapangan pekerjaan bagi beberapa orang yang memiliki keterampilan tersebut, sehingga dalam perananannya dalam dunia olahraga akan selalu dianggap penting dan selalu menjadi bentuk pelayanan yang melekat pada setiap acara-acara olahraga.

Perkembangan pijat atau massage saat ini semakin menunjukan perkembangan yang pesat. Terbukti dengan metode yang bervariasi yang dipadukan menjadi beberapa teknik tertentu untuk tujuan yang saling berkorelasi. Seperti melemaskan otot hingga mengurai asam laktat yang tertimbun pada suatu bagian otot. Massage saat ini tidak dapat dipandang sebelah mata. Dengan adanya perkumpulan yang membuat massage menjadi lebih terpercaya karena dapat dijelaskan dari aspek dan tujuan secara ilmiah.

Massage didefinisikan sebagai manipulasi manual dengan gerakan seperti menggosok, memijat, menekan, bergulir, menampar, dan mengetuk (Park et al., 2017, p. 789). Dalam dunia olahraga massage lebih cenderung dikenal dengan istilah sport massage, sport massage khusus diberikan pada seseorang yang sedang tidak sakit atau dalam kondisi sehat terutama olahragawan (Priyonoadi, 2008, p. 5).

Teknik sport massage saat ini semakin dikenal oleh kalangan luas, mulai dari olahragawan, pelaku olahraga secara umum, orang di luar olahraga dengan aktifitas sehari-hari seperti pekerja kantor, buruh dan lain sebagainya. Sport massage banyak diminati oleh berbagai kalangan karena dalam proses penanganan cenderung menyeuruh dan menggunakan berbagai macam teknik yang jika dirasakan akan sesuai dengan kebutuhan setiap orang, misalnya untuk relaksasi otot setelah seharian beraktifitas.

Tujuan dari sport massage secara umum merupakan tujuan yang ingin diperoleh oleh setiap orang, bahkan arah dan tujuan sport massage hampir sama dengan pijat kebugaran yang lainnya dan tentunya tujuan utamanya merupakan pengenduran otot yang tegang serta untuk arah melancarkan aliran dan peredaran darah. Sering dijumpai beberapa orang begitu menyukai massage bahkan hanya untuk pemenuhan hasrat keinginan dipijat bukan karena faktor kelelahan yang berarti, sehingga dari hal ini dapat dikatakan manusia memiliki kecenderungan untuk mengulangi suatu hal seperti sport massage untuk tujuan kesegaran tubuh semata. 
Teknik sport massage memiliki keragaman dan jenis beserta nama yang berbeda-beda, mulai dari menggosok, menggerus dan menampar atau dalam kata lain efflurage, petrisage, tapotement dan lain sebagainya. Tujuan dari beberapa teknik dalam sport massage yaitu untuk mengendurkan dan melancarkan aliran peredaran darah. Dengan jalan memijat menggerus, menggosok dan lain sebagainya.

Sport massage pada penjelasan sebelumnya dikatakan bahwa dilakukan untuk orang yang sehat, hal tersebut sesuai dengan pendapat yang mengatakan bahwa ada kondisi dimana hal tersebut tidak boleh dilakukan pemijatan, seperti patah atau retak tulang, dislokasi, peradangan, daging sendi, daging tumbuh, saat demam, disentri, dan ibu mengandung (Fondy, 2012, p. 58). Jadi jelas pemijatan terutama dalam sport massage hanya diperuntukan bagi orang sehat atau yang sedang tidak cedera.

Gerakan dalam pemijatan sport massage yang beraneka ragam sesuai dengan urutan dan tujuan akan membuat tubuh menjadi segar dan ringan karena peredaran darah menjadi lancar. Teknik efflurage atau gosokan biasanya lebih cenderung digunakan pada awal dan akhiran pemijatan, kemudian dalam proses pemijatan dapat dikombinasikan dengan teknik yang lain misalnya menggerus, meremas dan menampar, hal tersebut dengan tujuan yang sama yaitu mengendurkan otot dan melancarkan peredaran darah.

Manipulasi teknik gerakan dalam sport massage untuk berbagai tujuan yang akan memberikan relaksasi pada otot setelah aktifitas fisik. Bentuk penanganan dalam sport massage lebih menekankan menggunakan tangan atau bantuan tubuh lain dari masseur. Akan tetapi sering juga dijumpai seorang ahli massage dalam melakukan pemijatan menggunakan alat khusus untuk membantu pemijatan. Hal ini maksud dan tujuan sama yaitu alat bantu untuk relaksasi otot dan meningkatkan rentang gerak dan kinerja otot (Bradbury-Squires et al., 2015, p. 133).

Olahragawan atau atlet merupakan pelaku olahraga dengan tingkat keaktifan yang dikatakan tinggi dengan melihat program latihan yang dijalaninya. Sehingga seringkali terjadi kelelahan otot. kelelahan otot dapat terjadi setelah latihan dan bahkan lebih berbahaya jika terjadi saat bertanding. Kelelahan otot dapat diidentifikasi jika terjadinya kejang otot, yang disebabkan oleh tidak lancarnya proses resintesis asam laktat menjadi ATP kembali di dalam otot (Sukadiyanto \& Muluk, 2011, p. 38).
Dalam proses latihan atau saat bertanding atlet sangat penting diperhatikan kondisi fisiknya yang dalam hal ini pada tingkat kelelahan otot karena melalui sport massage yang diberikan sebelum bertanding dapat memberikan sumbangan atau tambahan dalam pemanasan fisik (Arabaci, 2008, p. 549). Melihat keterangan tersebut penting juga pelatih memahami berbagai bentuk penanganan yang bersifat antisipasi atau penanganan untuk mengontrol agar tidak terjadi cedera pada atlet seperti sport massage yang secara langsung hal ini dapat berfungsi untuk pencegahan terhadap cedera.

Seorang masseur tidak hanya dituntut untuk dapat memberikan penanganan ringan saat akan melakukan aktifitas dan sesudah aktifitas bagi olahragawan. Akan tetapi harus lebih memperhatikan dalam hal ini kecenderungan pada kelelahan otot bagi atlet yang dapat berdampak fatal seperti cedera sendi, dan yang mungkin sering terjadi yaitu cedera pada sendi ankle dimana jika hal itu terjadi maka akan sangat menganggu mobilitas sendi pergelangan kaki (Škarabot, Beardsley, \& Štirn, 2015, p. 205). Sehingga melalui teknik termasuk pemijatan dapat digunakan untuk meningkatkan pemulihan otot setelah melakukan latihan (Best, Hunter, Wilcox, \& Haq, 2008, p. 446).

Sekolah Khusus Olahraga Internasional Provinsi Kalimantan Timur dalam proses belajar dan pembelajarannya, tidak pernah terlepas dari visi dan misi Sekolah Khusus Olahraga Internasional Provinsi Kalimantan Timur agar dalam pencapaian tujuan dapat terlaksana dengan mudah serta dapat dievalusi tingkat keberhasilan proses belajar-mengajarnya. Untuk menunjang keberhasilan proses belajar mengajarnya.

Sekolah Khusus Olahraga Internasional Provinsi Kalimantan Timur memiliki beberapa sarana. seperti Stadion Madya Samarinda yang terdiri dari gedung bulu tangkis, gedung bela diri, gedung serbaguna, hotel atlet, lapangan parkir terbuka. Selain itu, ada beberapa sarana yang digunakan di luar Stadion Madya Samarinda misalnya Gedung Olahraga Anggar di Jalan Kadri Oening dan Kolam Renang GOR Segiri.

Selain itu, untuk meningkatkan prestasi olahraga di Kalimantan Timur serta memudahan pelatih dan guru untuk mengajar/melatih. Pihak Sekolah Khusus Olahraga Internasional Provinsi Kalimantan Timur mempunyai syarat-syarat tertentu dalam penyeleksian siswa yaitu pertama, lolos seleksi administrasi; kedua, memiliki persetujuan dari orang tua; ketiga, mendapat rekomendasi dari Dinas Pendidikan Kabupaten 
dan Kota serta Pengurus Cabang Olahraga Kabupaten, Kota dan Pengurus Provinsi cabang olahraga Kalimantan Timur.

Disamping itu, pihak Sekolah Khusus Olahraga Internasional Provinsi Kalimantan Timur juga melaksanakan tes fisik bagi siswa yang mendaftar di Sekolah Khusus Olahraga Internasional Provinsi Kalimantan Timur. Adapun tes fisik yang dilakukan adalah pengukuran berat badan, tinggi badan, panjang tungkai serta pemeriksaan kesehatan.

Keseriusan manajemen Sekolah Khusus Olahraga Internasional dalam membangun Sekolah Khusus Olahraga Internasional Provinsi Kalimantan Timur menunjukan bahwa Provinsi Kalimantan Timur tidak pernah menyerah dalam meningkatkan prestasi Provinsi Kalimantan Timur. Hal ini dengan selalu bertambahnya jumlah siswa dan pelatih untuk bergabung di Sekolah Khusus Olahraga Internasional Provinsi Kalimantan Timur.

Peran pelatih yang sangat besar dalam membangun prestasi olahraga Provinsi Kalimantan Timur mengharuskan pelatih yang memiliki berbagai macam keahlian. Salah satu keahlian yang dimiliki adalah menjadi masseur. Seorang ahli maseur harus memiliki pengetahun yang mendalam dibidang sport massage. Saat ini sport massage semakin menampakkan eksistensinya hal tersebut terlihat dari multi peran yang dimiliki dari beberapa pelatih khususnya di Sekolah Khusus Olahraga Internasional yang memiliki kemampuan sport massage.

Pelatih olahraga di Sekolah Khusus Olahraga Internasional Kalimantan Timur merupakan pelatih yang dapat dikatakan berpengalaman. Pelatih olahraga Sekolah Khusus Olahraga Internasional Provinsi Kalimantan Timur sebagian besar memiliki riwayat sebagai seorang atlet baik daerah hingga tingkat nasional, sehingga kemampuan dalam melatih khususnya pada cabang olahraga tertentu tidak diragukan lagi. Merujuk dari pernyataan tersebut tentunya seorang pelatih yang berpengalaman dalam beberapa event pertandingan tentunya akan mengerti pentingnya sport massage dalam dunia olahraga secara khusus bagi olahragawan atau atlet.

Pelatih olahraga khususnya di Sekolah Khusus Olahraga Internasional Provinsi Kalimantan Timur dalam menjalankan kegiatan melatih atau mendampingi atlet bertanding seringkali menemui berbagai kejadian hingga cedera pada atlet. Mengingat kondisi yang sering ditemui maka kiranya sangat penting bagi pelatih olahraga untuk lebih memahami sport massage. Hal tersebut terjadi saat di mana seorang tenaga masseur tidak selalu berada di dekat atlet yang sedang berlatih atau bertanding.

Pelatih olahraga di Sekolah Khusus Olahraga Internasional Provinsi Kalimantan Timur beberapa orang ada yang mempunyai kemampuan memijat dan tentunya dari hal itu dapat dikatakan bahwa pemijatan merupakan bagian penting dalam kehidupan para olahragawan. Selain itu dapat juga dikatakan bahwa pelatih olahraga Sekolah Khusus Olahraga Internasional Kalimantan Timur memiliki keinginan untuk mengembangkan kemampuan memijatnya terutama dengan teknik yang baik dan benar sesuai dengan ketentuan dan tepat sasaran.

Multi peran antara melatih dan kemampuan sport massage yang dimiliki oleh seorang pelatih sementara ini sangat terbatas sehingga dalam upaya pencegahan cedera bagi atlet sangat menggantungkan kepada tenaga masseur (Tukang Pijat). Seorang pelatih yang selalu berada di samping atlet saat latihan atau pertandingan diharapkan memiliki persepsi positif terhadap sport massage sehingga ke depannya dapat menumbuhkan minat atau rasa tertarik untuk mempelajari ilmu sport massage melalui berbagai pelatihan khusus untuk meningkatkan kemampuan khususnya sport massage dalam penanganan pencegahan cedera olahraga bagi atlet.

Persepsi seorang pelatih olahraga tidak berbeda dengan persepsi manusia pada umumnya yang memiliki sifat subjektif dalam memberikan anggapan hal tersebut bergantung pada keadaan setiap individu. Persepsi merupakan proses di mana masuknya pesan atau informasi ke dalam otak manusia (Slameto, 2010, p. 102). Melalui persepsi manusia akan melakukan hubungan dengan lingkungan dan dalam hal ini hubungan dilakukan melalui indranya yaitu: pengelihat, pendengar, peraba, perasa, dan pencium.

Persepsi yang dimiliki seorang pelatih olahraga di Sekolah Khusus Olahraga Internasional Provinsi Kalimantan Timur terkait sport massage berdasarkan studi pendahuluan yang dilakukan melalui wawancara awal menemukan pendapat baru terkait topik yang diangkat dalam penelitian ini. Diantaranya yaitu seorang pelatih olahraga di Sekolah Khusus Olahraga Internasional Provinsi Kalimantan Timur tidak semuanya memperhatikan manfaat dan pentingnya sport massage, di lain sisi pelatih olahraga Sekolah Khusus Olahraga Internasional Provinsi 
Kalimantan Timur sangat memahami dan memiliki persepsi atau anggapan positif,

Persepsi seorang pelatih Sekolah Khusus Olahraga nternasional Provinsi Kalimantan Timur merupakan anggapan khusus terhadap suatu hal. Selanjutnya berdasarkan sudut pandang atau anggapan pelatih mengenai sport massage diharapkan akan menumbuhkan rasa tertarik untuk lebih memahami dan mempelajari sport massage rasa tertarik tersebut cenderung mengarah pada minat untuk mengerti dan mempelajari sport massage. Pembahasan selanjutnya yaitu mengenai minat pelatih olahraga pada Sekolah Khusus Olahraga Internasional Provinsi Kalimantan Timur.

Minat seorang pelatih olahraga pada Sekolah Khusus Olahraga Internasional Provinsi Kalimantan Timur yang ke depannya akan menghantarkan pada motivasi untuk menjadi atau memperoleh dan mempelajari sesuatu, yang dalam hal ini tentunya sport massage yang dikaitkan dengan seorang pelatih olahraga di Sekolah Khusus Olahraga Internasional di Kalimantan Tmur, minat merupakan suatu bentuk rasa ingin atau rasa suka terhadap suatu hal, minat seorang pelatih olahraga terhadap sport massage merupakan rasa sukanya terhadap hal tersebut, minat merupakan persamaan dengan motif (Purwanto, 2009, p. 27).

Minat terhadap sport massage yang dimiliki oleh pelatih olahraga Sekolah Khusus Olagraga Internasional Provinsi Kalimantan Timur berdasarkan pengamatan awal dnegan cara wawancara sebagai studi pendahuluan menjelaskan bahwa pelatih memiliki minat yang tinggi untuk mempelajari sport massag. Pelatih olahraga Sekolah Khusus Olahraga Internasional sangat antusias untuk lebih memahami dan bahkan mempelajari keterampilan massage.

Pelatih olahraga Sekolah Khusus Olahraga Internasional Provinsi Kalimantan Timur merupakan pelatih yang berada di lingkungan sekolah olahraga di bawah pembinaan Dinas Pemuda dan Olahraga Provinsi Kalimantan Timur. Sekolah Khusus Olahraga Internasional Provinsi Kalimantan Timur merupakan pusat pembinaan olahraga yang disentralkan dengan sekolah menengan baik atas dan menengah yang tergabung di dalamnya.

Kondisi lingkungan yang mendukung untuk melakukan program latihan. Di mana Sekolah Khusus Olahraga Internasional terletak di kawasan stadion utama Palaran Samarinda provinsi Kalimantan Timur, merupakan pusat olahraga yang lengkap sarana dan prasarananya.
Selain itu Sekolah Khusus Olahraga Internasional Provinsi Kalimantan Timur terletak di Samarinda di Jalan Poros Lintas Samarinda Balikpapan. Tenaga pelatih yang tergabung di dalamnya merupakan pelatih yang berkompeten dalam bidangnya, dan memiliki pengalaman dalam bidang kepelatihan.

Studi pendahuluan yang dilakukan peneliti melalui kegiatan wawancara yang dilakukan pada pelatih dan unsur terkait yang ada di Sekolah Khusus Olahraga Internasional Provinsi Kalimantan Timur serta melihat proses latihan atlet secara langsung dapat menjelaskan beberapa hal. Terkait beberapa kendala yang dialami atlet saat berlatih terutama yang mengarah pada kondisi tubuh atlet atau fisik. Seringkali atlet mengalami beberapa gejala yang secara berkelanjutan terjadi seperti tidak optimal dalam melakukan latihan sehingga mempengaruhi efektifitas program latihan yang diberikan.

Pelatih dalam memberikan respon terhadap atlet saat latihan memiliki keragaman, seperti halnya mengarah pada kondisi psikologi atlet dan mengarah pada kondisi fisik. Kondisi fisik dalam hal ini yaitu jika terjadi kelelahan yang berarti hingga terjadinya cedera yang tidak terdeteksi secara cepat oleh pelatih yang dalam hal ini secara langsung bersinggungan dengan atlet setiap harinya. Pelatih olahraga dalam hal ini sering kurang tepat dalam memberikan persepsi terkait kondisi atlet yang seharusnya atlet diberikan penanganan massage akan tetapi tidak diperhatikan

Melihat beberapa hal yang terjadi selama latihan seringkali atlet merasakan kelelahan yang secara tidak langsung diucapkan. Kurangnya perlakuan yang mengarah pada terapi sport massage seperti diberikan penanganan shaking massage sebelum dan sesudah berlatih untuk mengurai sisa pembakaran atau mengurai asam laktat yang dapat memberikan efek tidak nyaman pada bagian otot tertentu. Keragaman mengenai anggapan dan minat pelatih terhadap sport massage menjadi daya tarik untuk diteliti

Penelitian ini penting dilakukan dalam rangka mendapat gambaran tentang persepsi pelatih olahraga Sekolah Khusus Olahraga Internasional Provinsi Kalimantan Timur terhadap sport massage dalam rangka sebagai tolok ukur dan peningkatan mutu pelatih dalam hal kemampuan sport massage pada masa yang akan datang sehingga pelatih mampu menerapkan keterarnpilan yang telah dimiliki dalam dunia olahraga atau masayarakat. 
Penelitian yang membahas sport massage juga dilakukan oleh (Kaplan et al., 2014, p. 142) yang menjelaskan dampak yang diberikan melalui sport massage terhadap ambang batas rasa sakit dan toleransi setelahnya. Kemudian hasilnya menunjukan bahwa sport massage itu memiliki dampak terhadap toleransi rasa sakit pada periode setelah latihan. menurut pemahaman yang diberikan ini adalah penelitian pertama yang mengevalusi efek sport massge terhadap tolernsi rasa sakit setelah latihan pada atlet.

Kondisi serupa sering dialami oleh atlet di Sekolah Khusus Olahraga Internasional di mana merasakan ketidak nyamanan setelah berlatih. Pada hal ini pelatih yang kesehariannya mendampingi atlet harus memiliki pendekatan dengan mengedepankan perhatian, melalui penelitian yang tingkat persepsi dan minat pelatih olahraga terhadap sport massage akan menjadi gambaran kepekaan pelatih terhadap atlet pada kondisi yang kurang baik misalkan kelelahan atau cedera setelah melakukan latihan

Kebaruan dalam penelitian ini yaitu untuk mendapatkan hasil data yang berupa persepsi dan minat pelatih olahraga terhadap sport massage kemudian kedepannya sebagai acuan berdasarkan hasil penelitian yang dilaksanakan untuk menjadi perhatian pihak terkait dalam melakukan pendalaman kemampuan melalui pelatihan khusus sport massage dan mendorong pelatih yang kurang peka terhadap pentingnya sport massage pada dunia olahraga serta untuk lebih memperhatikan dan mampu mengaplikasikannya.

Strategi pemecahan masalah pada masalah yang ada yaitu pelatih yang secara persepsi dan minat mungkin memiliki potensi yang tinggi tetapi kurang peka terhadap kondisi yang seharusnya melibatkan sport massage di dalamnya. Langkah yang harusnya dilakukan yaitu dengan memberikan dorongan pada pelatih untuk lebih memperhatikan kondisi yang membutuhkan penanganan sport massage serta penyuluhan dan bentuk pelatihan khusus terkait sport massage dan pengaplikasiannya dengan baik sesuai bentuk penanganan yang tepat.

Tujuan dalam penelitian ini untuk mengetahui sejauh mana sport massage dianggap penting di dalam dunia olahraga yang dalam hal ini yaitu pelatih cabang olahraga atau secara spesifik penelitian ini bertujuan untuk mengetahui persepsi dan minat pelatih olahraga Sekolah Khusus Olahraga Internasional Provinsi Kalimantan Timur terhadap Sport Massage.

\section{METODE}

Penelitian ini merupakan penelitian deskriptif kuantitatif yang bertujuan untuk mengetahui persepsi dan seberapa tinggi minat pelatih olahraga Sekolah Khusus Olahraga Internasional di Samarinda Kalimantan Timur terhadap Sport Massage. Jenis penelitian ini untuk memaparkan atau menggambarkan sesuatu hal, misalnya keadaan, kondisi, situasi, kegiatan (Arikunto, 2010, p. 3). Metode yang digunakan adalah survei, tekhnik pengambilan data menggunakan angket, skor yang diperoleh dianalisis menggunakan analisis diskriptif kuantitatif yang dituangkan dalam bentuk prosentase.

Populasi dalam penelitian ini adalah seluruh pelatih dan asisten pelatih cabang olahraga yang ada di Sekolah Khusus Olahraga Internasional, Kota Samarinda, Provinsi Kalimantan Timur yang berjumlah 32 orang. Penelitian ini menggunakan teknik sampling jenuh yaitu teknik penentuan sampel bila semua anggota populasi digunakan sebagai sampel (Sugiyono, 2015, p. 124), atau dengan kata lain penelitian ini adalah penelitian populasi dengan sampel seluruh pelatih dan asisten pelatih cabang olahraga yang ada di Sekolah Khusus Olahraga Internasional, Samarinda Provinsi Kalimantan Timur dengan jumlah keseluruhan 32 orang pelatih cabang olahraga yang ada di Sekolah Khusus Olahraga Internasional.

Penelitian ini dilaksanakan di Sekolah Khusus Olahraga Internasional (SKOI) yang terletak di kawasan olahraga atau stadion utama Palaran, Samarinda, Provinsi Kalimantan Timur. Pengambilan data dilaksanakan pada tanggal 22 Februari 2018-9 April 2018. Subjek penelitian ini adalah seluruh pelatih olahraga Sekolah Khusus Olahraga Internasional Provinsi Kalimantan Timur dengan jumlah 32 Responden.

Penelitian ini menggunakan instrumen berupa angket atau kuesioner untuk mengumpulkan data. Pengumpulan data menggunakan angket persepsi dan minat pelatih olahraga Sekolah Khusus Olahraga Internasional di Kota Samarinda, Provinsi Kalimantan Timur terhadap sport massage. Pernyataan berupa angket disusun dengan menggunakan skala likerts. Untuk memberikan skor dari setiap pernyataan yang dijawab oleh responden yang positif diberikan skor: SS $($ sangat setuju $)=5, \mathrm{~S}($ setuju $)=4, \mathrm{KS}$ (kurang setuju $)=3$, TS $($ tidak setuju $)=2$, STS (sangat tidak setuju $)=1$ 
Dalam proses persepsi dan minat tersebut individu akan mengadakan penafsiran mengenai sport massage.

Teknik analisis data dalam penelitian ini menggunakan teknik statistik deskriptif yang dituangkan dalam bentuk persentase,

$$
\mathrm{P}=\frac{f}{N} x 100 \%
$$

Keterangan:

$\mathrm{P}=$ persentase

$\mathrm{f}=$ frekuensi yang sedang dicari

$\mathrm{N}=$ jumlah total frekuensi

(Sudijono, 2012, p. 43).

Pengubahan skor mentah menjadi hasil nilai standar menggunakan Mean (M) dan standar deviasi (SD) berskala lima, Tabel 1 merupakan norma penilaian persepsi siswa:

Tabel 1. Norma Penilaian Persepsi dan Minat

\begin{tabular}{ll}
\hline \multicolumn{1}{c}{ Interval Skor } & \multicolumn{1}{c}{ Kategori } \\
\hline$>\mathrm{M}+1,5 \mathrm{SD}$ & Baik Sekali \\
$\mathrm{M}+0,5 \mathrm{SD}(\mathrm{s} / \mathrm{d}) \mathrm{M}+1,5 \mathrm{SD}$ & Baik \\
$\mathrm{M}-0,5 \mathrm{SD}(\mathrm{s} / \mathrm{d}) \mathrm{M}+0,5 \mathrm{SD}$ & Cukup \\
$\mathrm{M}-1,5 \mathrm{SD}(\mathrm{s} / \mathrm{d}) \mathrm{M}-0,5 \mathrm{SD}$ & Kurang \\
$<\mathrm{M}-1,5 \mathrm{SD}$ & Kurang Sekali \\
\hline
\end{tabular}

Keterangan:

$\mathrm{M}=$ Mean/ rerata

$\mathrm{SD}=$ Standar Deviasi

\section{HASIL DAN PEMBAHASAN}

Pada penelitian ini menggunakan dua angket, yaitu angket persepsi dan minat pelatih olahraga pada Sekolah Khusus Olahraga Internasional Provinsi Kalimantan Timur dengan masing-masing item pernyataan yang sudah diuji cobakan sebagai syarat validitas dan reliabilitas alat tes. Data penelitian diperoleh dari angket yang diisi oleh responden sebanyak 32 pelatih olahraga Sekolah Khusus Olahraga Internasional Provinsi Kalimantan Timur.

Data persepsi dan minat sebelumnya dideskripsikan, dengan tujuan untuk mempermudah penyajian penelitian. Hasil analisis deskriptif data Persepsi dan minat pelatih olahraga Sekolah Khusus Olahraga Internasional Provinsi Kalimantan Timur terhadap sport massage adalah sebagai berikut.

Untuk memperjelas dari penelitian yang berjudul persepsi dan minat pelatih olahraga terhadap sport massage maka akan dipaparkan deskripsi data hasil penelitian pada persepsi pelatih olahraga Sekolah Khusus Olahraga Internasional Provinsi Kalimantan Timur: Mean atau rerata (92,6), Median, (93), Modus (79),
Standar Deviasi $(12,34)$, skor minimal (65), skor maksimal (117). Deskripsi data hasil penelitian pada minat pelatih olahraga Sekolah Khusus Olahraga Internasional Provinsi Kalimantan Timur: Mean (85,9), Median, (88), Modus (76), Standar Deviasi $(16,2)$, skor minimal (58), skor maksimal (110).

Data hasil penelitian tentang persepsi dan minat pelatih olahraga Sekolah Khusus Olahraga Internasional Provinsi Kalimantan Timur terhadap Sport Massage, selanjutnya akan disajikan dalam perhitungan kategorial. Untuk mengetahui secara lebih rinci dari masing-masing angket persepsi dan minat pelatih olahraga pada Sekolah Khusus Olahraga Internasional Provinsi Kalimantan Timur, untuk lebih jelasnya mengenai hasil angket persepsi dapat dilihat pada hasil Tabel 2.

Tabel 2. Perhitungan Kategorial persepsi pelatih olahraga Sekolah Khusus Olahraga Internasional Provinsi Kalimantan Timur terhadap Sport Massage

\begin{tabular}{cccc}
\hline Kategori & Interval & F & $\%$ \\
\hline Baik Sekali & $\mathrm{X}>111$ & 1 & 3,1 \\
Baik & $99<\mathrm{X} \leq 111$ & 12 & 37,5 \\
Cukup & $86<\mathrm{X} \leq 99$ & 7 & 21,9 \\
Kurang & $74<\mathrm{X} \leq 86$ & 11 & 34,4 \\
Kurang Sekali & $\mathrm{X}<74$ & 1 & 3,1 \\
Jumlah & & 32 & 100 \\
\hline
\end{tabular}

Dari data Tabel 2 dapat dijelaskan tentang persepsi pelatih olahraga pada Sekolah Khusus Olahraga Internasional Provinsi Kalimantan Timur terhadap sport massage pada kategori baik sekali 1 atau 3,1\%, kategori Baik 12 atau sebesar $37,5 \%$, pada kategori cukup 7 atau sebesar $21,9 \%$, kategori kurang 11 atau sebesar $34,4 \%$ kemudian pada kategori kurang sekali 1 atau sebesar $3,1 \%$.

Berdasarkan hasil tersebut dapat dijelaskan bahwa persepsi pelatih olahraga Sekolah Khusus Olahraga Internasional Kalimantan Timur termasuk ke dalam kategori baik yaitu sejumlah 12 pelatih olahraga atau sebesar 37,5\%. Apabila ditampilkan dalam bentuk diagram terlihat pada Gambar 1.

Berdasarkan Gambar 1 menambah penjelasan bahwa persepsi pelatih olahraga Sekolah Khusus Olahraga Internasional Provinsi Kalimantan Timur termasuk ke dalam kategori baik yaitu 12 orang pelatih atau $37,5 \%$.

Selanjutnya sesuai dengan tema dalam penelitian ini yaitu persepsi dan minat pelatih olahraga terhadap sport massage, maka selanjutnya akan dijelaskan tentang minat pelatih olah- 
raga Sekolah Khusus Olahraga Internasional Provinsi Kalimantan Timur terhadap sport massage di mana disajikan ke dalam Tabel 3.

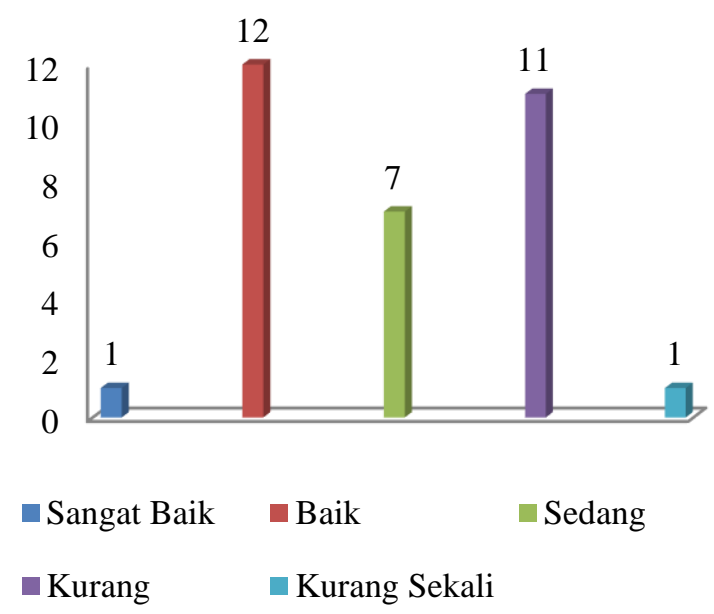

Gambar 1. Diagram Batang Persepsi Pelatih Olahraga Sekolah Khusus Olahraga Internasional Provinsi Kalimantan TImur terhadap Sport Massage.

Tabel 3. Perhitungan Kategorial Minat Pelatih Olahraga Sekolah Khusus Olahraga Internasional Provinsi Kalimantan Timur terhadap Sport Massage

\begin{tabular}{cccc}
\hline Kategori & Interval & F & \% \\
\hline Baik Sekali & $\mathrm{X}>110$ & 0 & 0,0 \\
Baik & $94<\mathrm{X} \leq 110$ & 12 & 37,5 \\
Cukup & $78<\mathrm{X} \leq 94$ & 7 & 21,9 \\
Kurang & $62<\mathrm{X} \leq 78$ & 10 & 31,3 \\
Kurang Sekali & $\mathrm{X}<62$ & 3 & 9,4 \\
\hline \multicolumn{5}{c}{ Jumlah } & 32 & 100 \\
\hline
\end{tabular}

Dari data Tabel 3 dapat dijelaskan minat pelatih olahraga pada Sekolah Khusus Olahraga Internasional Provinsi Kalimantan Timur terhadap sport massage pada kategori baik sekali 0 atau $0,0 \%$, kategori Baik 12 atau sebesar 37,5\%, pada kategori cukup 7 atau sebesar $21,9 \%$, kategori kurang 10 atau sebesar 31,3\% kemudian pada kategori kurang sekali 3 atau sebesar 9,4\%.

Berdasarkan hasil tersebut dapat dijelaskan bahwa minat pelatih olahraga Sekolah Khusus Olahraga Internasional Kalimantan Timur termasuk ke dalam kategori baik yaitu sejumlah 12 pelatih olahraga atau sebesar $37,5 \%$. Data tersebut menjelaskan rasa ingin atau minat pelatih terhadap sport massage tergolong tinggi bahkan untuk mempelajarinya, dan mengaplikasikan dalam kondisi tertentu terutama pada kondisi yang darurat saat berlatih, istirahat atau bertanding bagi atlet. Selanjutnya apabila ditampilkan dalam bentuk diagram terlihat pada Gambar 2.



Gambar 2. Diagram Batang Minat Pelatih Olahraga Sekolah Khusus Olahraga Internasional Provinsi Kalimantan Timur terhadap Sport Massage.

Berdasarkan Gambar 2 menambah penjelasan bahwa persepsi pelatih olahraga Sekolah Khusus Olahraga Internasional Provinsi Kalimantan Timur termasuk ke dalam kategori baik yaitu 12 orang pelatih atau 37,5\%.

Berdasarkan hasil penelitian yang telah disajikan maka selanjutnya akan dijelaskan dalam pembahasan. Hasil yang diperoleh menunjukkan bahwa persepsi pelatih olahraga Sekolah Khusus Olahraga Internasional Kalimantan Timur termasuk ke dalam kategori baik yaitu sejumlah 12 pelatih olahraga atau sebesar 37,5\%.

Hasil tersebut menandakan bahwa pelatih olahraga di Sekolah Khusus Olahraga Internasional Kalimantan Timur memiliki anggapan yang baik mengenai bentuk kegiatan sport massage. Sehingga selanjutnya dapat dikatakan pelatih memiliki kepedulian terhadap kondisi fisik atlet atau olahragawan secara umum.

Berdasarkan hasil penelitian maka selanjutnya akan dibahas terkait minat pelatih olahraga Sekolah Khusus Olahraga Internasional Kalimantan Timur terhadap sport massage menunjukkan bahwa minat pelatih olahraga Sekolah Khusus Olahraga Internasional Kalimantan Timur termasuk ke dalam kategori baik yaitu sejumlah 12 pelatih olahraga atau sebesar 37,5\%.

Hal tersebut jika dipahami secara menyeluruh dipengaruhi oleh beberapa faktor diantaranya yaitu lingkungan olahraga yang menjadi rutinitas sehari-hari. Sehingga pelatih sangat memahami dan peka terhadap kondisi di lapangan serta memahami tentang peran sport massage di dalam dunia olahraga, baik saat atlet berlatih atau saat bertanding, sehingga anggapan 
pelatih spirt massage tentunya ke arah positif atau baik.

Terkait minat pelatih maka tentunya akan mengarah pada kebiasaan dan pengembangan diri untuk lebih mengetahui dan mampu mengaplikasikan pada saat terjadi hal-hal yang sifatnya membutuhkan penanganan seperti sport massage contohnya. Kemudian di sisi lain para pelatih yang pada kenyataannya hidup di lingkungan masyarakat secara umum sehingga minat untuk berkembang melalui sport massage yang dikemas dan diaplikasikan ke arah berwirausaha di luar melatih atau di lingkungan masyarakat umum menjadi alasan yang dapat diterima akal.

Pernyataan di atas menjelaskan bahwa pelatih cabang olahraga di Sekolah Khusus Olahraga Internasional Kalimantan Timur memiliki keinginan kuat serta anggapan baik terhadap sport massage. Hal tersebut berdasarkan hasil penelitian dan observasi awal yang dilakukan dapat dijelaskan bahwa beberapa pelatih sangat aktif saat diwawancara terkait sport massage sebagai studi pendahuluan atau observasi awal yang dilakukan sebelum menentukan topik judul dan metode penelitian.

Keadaan ini dipengaruhi oleh beberapa faktor diantaranya faktor instrinsik dan faktor ekstrinsik. Hasil ini menunjukkan seberapa besar persepsi dan minat pelatih olahraga Sekolah Khusus Olahraga Internasional terhadap Sport Massage dan apa saja faktor yang mempengaruhinya. persepsi dan minat pelatih olahraga Sekolah Khusus Olahraga Internasional terhadap Sport Massage sangat berpengaruh terhadap rasa ingin untuk lebih mempelajari sport massage dan melanjutkan ke dalam proses pelatihan untuk lebih menguasai kemampuan sport massage.

Pelatih olahraga Sekolah Khusus Olahraga Internasional Kalimantan Timur cenderung memiliki persepsi dan minat yang baik atau tinggi dikarenakan dalam proses program latihan seringkali menjumpai kejadian cedera olahraga sehingga dapat dijelaskan bahwa para pelatih olahraga diharapkan tergugah untuk lebih memperhatikan kondisi atlet serta mendalami kemampuan sport massage untuk bekal dan kemampuan penunjang bagi pelatih yang dapat digunakan dalam lingkungan olahraga dan masyarakat secara umum. dengan adanya penelitian ini terkait persepsi dan minat pelatih terhadap sport massage akan meningkatkan rasa peduli dan keinginan untuk menguasai teknik dasar sport massage.

Merujuk dari hasil penelitian yang menjelaskan bahwa persepsi dan minat pelatih olahraga dalam kategori baik dalam hal ini secara khusus pada Sekolah Khusus Olahraga Internasional Provinsi Kalimantan Timur, hal tersebut menjelaskan bahwa hubungan atau keterkaitan yang menjelaskan bahwa memijat merupakan budaya atau membudaya dan menjadi kebiasaan yang sudah dilakukan sejak zaman dahulu sehingga dalam hal ini merupakan suatu penjelasan untuk memantabkan pendapat bahwa memijat merupakan kebiasaan sejak zaman nenek moyang.

Kondisi pada studi pendahuluan yang dilakukan menjelaskan bahwa terdapat keragaman pendapat pelatih mengenai sport massage dalam dunia olahraga atau kepelatihan akan tetapi dalam penerapannya seringkali pelatih kurang memperhatkan kapan dan bagaimana sport massage digunakan pada atlet. Sedangkan setelah dilakukan penelitian yang membahas persepsi dan minat pelatih terhadap sport massage mendapatkan hasil baik dari keduanya, hal tersebut terdapat sedikit ketidaksesuaian yang ke depannya diharapkan akan lebih mendapat perhatian dari pihak-pihak yang terkait di dalamnya.

Secara umum hasil penelitian yang menjelaskan bahwa persepsi dan minat terhadap sport massage dalam kategori baik menjelaskan bahwa olahraga, atlet, dan pelatih memiliki keterkaitan yang tidak dapat dipisahkan. Sport massage merupakan upaya dalam pencegahan terhadap cedera yang dala hal ini pelatih yang merupakan seseorang yang sering bersinggungan dengan atlet. Sehingga akan lebih peka terhadap kondisi yang terjadi di lapangan.

\section{SIMPULAN}

Berdasarkan hasil penelitian dan pembahasan yang telah dipaparkan sebelumnya maka kesimpulan dalam penelitian ini yaitu pelatih cabang olahraga di Sekolah Khusus Olahraga Internasional Kalimantan Timur memiliki anggapan atau persepsi dan minat positif atau baik terhadap sport massage, hal tersebut dibuktikan dengan hasil yang menunjukan kategori baik pada penelitian yang dilakukan terhadap tingkat persepsi dan minat pelatih terhadap sport massage.

\section{DAFTAR PUSTAKA}

Arabaci, R. (2008). Acute effects of pre-event lower limb massage on explosive and high speed motor capacities and flexibility. Journal of Sports Science and Medicine, 07(4), 549-555. Retrieved from 
https://www.jssm.org/hfabst.php?id=jssm $-07-549 . x m l$

Arikunto, S. (2010). Prosedur penelitian: Suatu pendekatan praktik. Jakarta: Rineka Cipta.

Best, T. M., Hunter, R., Wilcox, A., \& Haq, F. (2008). Effectiveness of sports massage for recovery of skeletal muscle from strenuous exercise. Clinical Journal of Sport Medicine: Official Journal of the Canadian Academy of Sport Medicine, 18(5), $\quad$ 446-460. https://doi.org/10.1097/JSM.0b013e31818 $837 \mathrm{a} 1$

Bradbury-Squires, D. J., Noftall, J. C., Sullivan, K. M., Behm, D. G., Power, K. E., \& Button, D. C. (2015). Roller-massager application to the quadriceps and kneejoint range of motion and neuromuscular efficiency during a lunge. Journal of Athletic Training, 50(2), 133-140. https://doi.org/10.4085/1062-605049.5.03

Fondy, T. (2012). Merawat dan mereposisi cedera tubuh. Tangerang: Pustaka Tumbur.

Kaplan, A. S., Uğurlu, S. B., Pamuk, Ö., Özdemir, Ö., Hindistan, I. E., \& Özkaya, Y. G. (2014). Effect of sport massage on pressure pain threshold and tolerance in athletes under eccentric exercise. International Journal of Science Culture and Sport, 2(6), 136-136.
https://doi.org/10.14486/IJSCS185

Park, J., Shim, J., Kim, S., Namgung, S., Ku, I., Cho, M., ... Roh, H. (2017). Application of massage for ankle joint flexibility and balance. Journal of Physical Therapy Science, 29(5), 789-792. https://doi.org/10.1589/jpts.29.789

Priyonoadi, B. (2008). Sport massage. Yogyakarta: Fakultas Ilmu Keolahragaan, Universitas Negeri Yogyakarta.

Purwanto, M. N. (2009). Psikologi pendidikan. Remaja Rosdakarya. Bandung: PT Remaja Rosdakarya.

Škarabot, J., Beardsley, C., \& Štirn, I. (2015). Comparing the effects of self-myofascial release with static stretching on ankle range-of-motion in adolescent athletes. International Journal of Sports Physical Therapy, 10(2), 203-212.

Slameto. (2010). Belajar dan faktor-faktor yang mempengaruhinya. Jakarta: PT Rineka Cipta.

Sudijono, A. (2012). Pengantar evaluasi pendidikan. Jakarta: PT Raja Grafindo Persada.

Sugiyono. (2015). Metode penelitian pendidikan: Pendekatan kuantitatif, kualitatif, dan $R \&$ $D$. Bandung: Alfabeta.

Sukadiyanto \& Muluk, D. (2011). Pengantar teori dan metodologi melatih fisik. Bandung: Lubuk Agung. 